quently: the degree of assistance to be called "reference." Do we do it for them, or do we teach them to do it for themselves? While advocating "maximum" service the author recognizes the teaching aspect of day-to-day reference. He prefers that in practice we do whatever is required to answer the question, and then some. His common sense view is to do what the situation calls for. This reviewer likes this book, partly because he agrees with its pragmatic philosophy, but also for such statements as, "Man has forgotten more than he has remembered and lost more than he has recorded. A large amount of research involves trying to find it again."

The bibliography might be more complete, but major writers are represented and, of course, similar lists abound. A good, workable index is included.

Reference students and librarians needing a refresher will find this a useful and thought-provoking book.-James F. Parks, Millsaps College, Jackson, Mississippi.

\section{The Future of the National Library of}

Canada. Ottawa: National Library of Canada, 1979. 88, 93p. Free. ISBN 0662-50628-6. Text in English and French, each with special t.p. and separate paging. French text on inverted pages. (Available from: National Library of Canada.)

Among the august company of national libraries, the National Library of Canada is a mere youth, having celebrated its twentyfifth anniversary less than two years ago. During its short life it has grown from a staff of 14 with a total budget of $\$ 76,600$ to a staff of 490 with a budget approaching $\$ 15$ million.

This report on the role of the National Library is the culmination of three years of intensive study and review of past achievements and an effort to define the needs and directions of the future. The report begins with a summary of the results of this study-eleven recommendations for organization and development. The remaining pages are an effort to support these recommendations.

In theory it is difficult to argue with these goals and objectives. The library does need better funding; the retrospective collection should be strengthened to meet research requirements; the acts of Parliament governing the library and related services need clarification; more space is needed; and, finally, it is not unreasonable to suggest that the nation's printed documentation should be under the jurisdiction of its national library.

Unfortunately, the National Library of Canada has not yet earned the full confidence of Canadian librarians nor of the general public. Too often the grand designs have become lost in a maze of studies or been pushed further and further into the future with few signs of fruition.

The recommendations destined to stir up the greatest controversies are those concerning the National Map Collection (now part of the National Archives) and the Canada Institute for Scientific and Technical Information (CISTI). For more than seventyfive years before the creation of the National Library, functions which might normally have been considered part of its mandate were performed by the National Archives. The development of the National Map Collection is a case in point. It functions well, its staff is active in the creation of international bibliographic and cataloging standards, and it fears disruptions and delays if the collection becomes part of the National Library.

The collection and dissemination of scientific information in Canada has for many years been carried out by CISTI under the jurisdiction of the National Research Council, a Crown Corporation. It has developed a comprehensive scientific collection, a sophisticated computerized information service, and it provides prompt service and documentation to all parts of the nation's scientific community. It is a service far beyond that which the National Library has managed to provide in the humanities and social sciences, yet the report recommends that CISTI become part of the National Library and report directly to the national librarian.

In discussing Canada's research resources and the need for networking, the report downplays the efforts already made when it states: "The benefits of cooperation on a provincial or regional basis have been explored in a preliminary way by the Ontario 
Council of University Librarians, the Conseil des Recteurs des Universités du Québec, the Association of Atlantic Universities and the Librarians of Western Canadian Universities, including those of British Columbia." Their efforts have gone far beyond the preliminary stages. Ontario and Quebec libraries have been sharing cataloging records, trying to rationalize collections, and running a daily interlibrary loan delivery service for the better sharing of collections since 1974. What the National Library needs to do is find a way to link these networks, not ignore them and start again. Networking in Canada faces two major problems that cannot be ignored: a small population and an immense geographical area. These make regional developments all the more important.

The National Library must first prove to the nation that it is capable of providing reliable service and leadership in those areas that have been its responsibility for nearly three decades before demanding the control or abolition of services that already operate efficiently.

The report is followed by several appendixes, including a somewhat idealistic outline of a Canadian library network as envisaged by the National Library; the text of the National Library Act; an organization chart for the library; and several tables of budgets and expenditures for various types of libraries across the country. Finally, there is a three-page bibliography of relevant materials.

The report will be the subject of much discussion by Canadian library groups and in government circles in the coming months. It should lead to a critical examination of the reasons why librarians and researchers across the country are still so skeptical of the library's abilities.-Dorothy F. Thomson, University of Ottawa, Ottawa, Canada.

Manheimer, Martha L. OCLC: An Introduction to Searching and Input. New York: Neal-Schuman, 1979. 64p. \$8.50. LC 79-23985. ISBN 0-918212-38-3. (May be purchased for classroom use at $\$ 4.95$ each, minimum order five copies.)

With more than two thousand libraries in fifty states employing the services of OCLC for cataloging and interlibrary loan, publications that offer guidance in using the system are always welcome. OCLC provides its own documentation, of course, and with the publication of On-Line Systems has greatly improved the organization and method of updating its material. As the bibliographic utility has expanded and refined its services, however, the size and complexity of the documentation has increased and can appear overwhelming to the novice.

OCLC: An Introduction to Searching and Input answers the need for a concise, simplified manual for the person unfamiliar with the OCLC system. Martha L. Manheimer, an associate professor of library science at the University of Pittsburgh Graduate School of Library and Information Science, demonstrates a thorough knowledge of her subject and considerable expertise in presenting it. The purpose of her book as stated in the introduction is ". . . to pro-

\section{Brockhaus/GermanBooks}

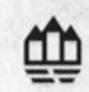

Publications from Germany, Austria and Switzerland. Complete Periodical Service: traditionally reliable and efficient.

For information write to us. 